\title{
Influence of Irrigation Regimes and Nitrogen Levels on Growth, Yield and Water Productivity of Rice under Alternate Wetting and Drying (AWD) Method of Water Management
}

\author{
P. Srinivasulu*, V. Ramulu, M. Uma Devi and G. Sreenivas
}

Department of Agronomy (Water Management), College of Agriculture, Rajendranagar, Hyderabad, Professor Jayashankar Telangana State Agriculture University, India

*Corresponding author

\begin{abstract}
A B S T R A C T
Keywords

Irrigation regimes,

Nitrogen levels,

Water productivity

Article Info

Accepted:

26 March 2018

Available Online:

10 April 2018

A field experiment was carried out during kharif 2015 on clay loam soil at college farm, Rajendranagar, Hyderabad with an objective to study the response of rice to irrigation regimes and nitrogen levels under AWD method of water management. The experiment was laid out in a split plot design with three replications. Three irrigation regimes were taken as main plots and three nitrogen levels in subplots include S1: Transplanted low land rice with continuous submergence of $3 \mathrm{~cm}$ up to panicle initiation stage and then $5 \mathrm{~cm}$ up to maturity, S2: AWD water management of periodical flooding to $3 \mathrm{~cm}$ submergence depth from 15 DAT to maturity when the ponded water disappears on the ground surface, S3: AWD water management of periodical flooding of the field to $5 \mathrm{~cm}$ submergence depth from 15 DAT to maturity when the ponded water level drops to $5 \mathrm{~cm}$ below ground level in the field tube and nitrogen levels viz., $\mathrm{N} 1: 120 \mathrm{~kg} \mathrm{ha}^{-1}, \mathrm{~N} 2: 160 \mathrm{~kg} \mathrm{ha}^{-1}, \mathrm{~N} 3: 200 \mathrm{~kg} \mathrm{ha}^{-1}$ ). The results revealed that the combination continuous submergence of $3 \mathrm{~cm}$ up to panicle initiation stage and then $5 \mathrm{~cm}$ up to maturity and $200 \mathrm{~kg} \mathrm{~N}$ ha-1 was found to be the best for higher yield $(6562 \mathrm{~kg} / \mathrm{ha})$ and water productivity compared to the other irrigation regimes and nitrogen levels under AWD method of water management.
\end{abstract}

\section{Introduction}

The water crisis is threatening the sustainability of the irrigated rice system and food security in Asia. Tuong and Bouman (2003) indicated that 2 million ha of irrigated dry-season rice and 13 million ha of irrigated wet-season rice in Asia will experience "physical water scarcity" by 2025. Most of the 22 million ha of irrigated dry-season rice in south and Southeast Asia will suffer "economic water scarcity". There was also much evidence that water scarcity already prevails in rice growing areas (Bouman et al., 2002), where farmers need technologies to cope with water shortage and ways must be sought to grow rice with less water. Among the various essential nutrient elements, nitrogen plays a pivotal role for growth and metabolic processes in rice plants. Nitrogen management in rice field is different from other crops because of the continuous submergence of the field. Consequently environment of root zone is converted from 
aerobic to anaerobic conditions. Excessive nitrogen promotes lodging and diseases ultimately reduction in yield of rice. Hybrid rice is more fertilizer responsive, but information about agronomic technology on hybrid rice particularly on nutrition is meager. The present strategy of increasing food production essentially involved the balance use of fertilizers to hybrid rice, because all the varieties of hybrid rice give their fully yield potential with adequate supply of nutrients. Keeping these points in view the present study is proposed to evaluate the influence of irrigation regimes and nitrogen levels on growth, yield of rice under AWD method of water management.

\section{Materials and Methods}

A field experiment was conducted at college farm, Rajendranagar, Hyderabad during kharif, 2015. The soil was sandy clay loam in texture, slightly alkaline in reaction and nonsaline. The fertility status of the experimental soil was low in available nitrogen, high in available phosphorous and potassium, available N (253 kg/ha), P (42 kg/ha) and K (238) in the $0-30 \mathrm{~cm}$ soil layer. The treatments comprised three irrigation regimes, viz. S1: Transplanted low land rice with continuous submergence of $3 \mathrm{~cm}$ up to panicle initiation stage and then $5 \mathrm{~cm}$ up to maturity, S2: AWD water management of periodical flooding to 3 $\mathrm{cm}$ submergence depth from15 DAT to maturity when the ponded water disappears on the ground surface, S3: AWD water management of periodical flooding of the field to $5 \mathrm{~cm}$ submergence depth from 15 DAT to maturity when the ponded water level drops to $5 \mathrm{~cm}$ below ground level in the field tube and nitrogen levels viz., N1:120 kg ha ${ }^{-1}, \mathrm{~N} 2: 160$ $\mathrm{kg} \mathrm{ha}^{-1}, \mathrm{~N} 3: 200 \mathrm{~kg} \mathrm{ha}^{-1}$ in the sub plot splitplot design with three replications. Recommended dose of $\mathrm{N}$ was considered as $120 \mathrm{~kg} / \mathrm{ha}$. The Rice variety MTU 1010 with the duration of 120-125 days was raised and was transplanted on 16 August 2015 at a spacing of $15 \times 15 \mathrm{~cm}$. A uniform dose of 60 $\mathrm{kg} \mathrm{P}_{2} \mathrm{O}_{5} /$ ha through single superphosphate and $40 \mathrm{~kg} \mathrm{~K} \mathrm{~K}_{2} \mathrm{O} / \mathrm{ha}$ through muriate of potash as well as half the nitrogen through urea as per treatment was applied basal, whereas the remaining dose of nitrogen was applied in two equal splits as top-dressing at tillering and panicle initiation-stage of rice. During the crop period, a total rainfall of $360 \mathrm{~mm}$ was received.

\section{Results and Discussion}

\section{Irrigation regimes}

Maximum plant height, LAI, Drymatter accumulation was observed with continuous submergence of $3 \mathrm{~cm}$ up to panicle initiation stage and then $5 \mathrm{~cm}$ up to maturity which was significantly superior to AWD water management of periodical flooding of the field to $5 \mathrm{~cm}$ submergence depth from 15 DAT to maturity when the ponded water level drops to $5 \mathrm{~cm}$ below ground level in the field tube (Table 1) continuous submergence of $3 \mathrm{~cm}$ up to panicle initiation stage and then $5 \mathrm{~cm}$ up to maturity registered higher number of panicles $\mathrm{m}-2$, grains/panicle over AWD water management of periodical flooding of the field to $5 \mathrm{~cm}$ submergence depth from 15 DAT to maturity when the ponded water level drops to $5 \mathrm{~cm}$ below ground level in the field tube.

It provided a better conductive rhizosphere condition for better uptake of nutrients and in turn helped the plants to boost their growth, leading to the development of yield attributes through supply of more photosynthates towards reproductive sink (Dhar et al., 2000). Compared to flood irrigation or complete submergence throughout the crop period, maintaining shallow water depth with wetting and drying decreased vertical $\mathrm{NH} 4+\mathrm{N}$ and total nitrogen leaching. Complete submergence throughout the crop period, on the other hand, leads to continuous hypoxic condition. 
Table.1 Plant height $(\mathrm{cm})$, LAI and Dry matter accumulation $\left(\mathrm{gm}^{-2}\right)$ as influenced by irrigation regimes and $\mathrm{N}$ levels under AWD method of water management in rice at harvest

\begin{tabular}{|c|c|c|c|}
\hline Treatment & $\begin{array}{l}\text { Plant height } \\
\text { (cm) }\end{array}$ & LAI & $\begin{array}{l}\text { Dry matter } \\
\text { Accumulation (g } \\
\left.\mathbf{m}^{-2}\right)\end{array}$ \\
\hline \multicolumn{4}{|c|}{ Main Plots: Irrigation Regimes (S) } \\
\hline $\begin{array}{l}\mathrm{S}_{1} \text { - Transplanted low land } \\
\text { rice with continuous } \\
\text { submergence of } 3 \mathrm{~cm} \text { up to } \\
\text { panicle initiation stage and } \\
\text { then } 5 \mathrm{~cm} \text { up to maturity }\end{array}$ & 105.48 & 4.03 & 1294.44 \\
\hline $\begin{array}{l}\mathrm{S}_{2}-\mathrm{AWD} \\
\text { management of periodical } \\
\text { flooding to } 3 \text { cm } \\
\text { submergence depth from } 15 \\
\text { DAT to maturity when the } \\
\text { ponded water disappears on } \\
\text { the ground surface. }\end{array}$ & 105.65 & 4.39 & 1281.44 \\
\hline $\begin{array}{l}\mathrm{S}_{3}-\mathrm{AWD} \text { water } \\
\text { management of periodical } \\
\text { flooding of the field to } 5 \mathrm{~cm} \\
\text { submergence depth from } 15 \\
\mathrm{DAT} \text { to maturity when the } \\
\text { ponded water level drops to } \\
5 \mathrm{~cm} \text { below ground level in } \\
\text { the field water tube. }\end{array}$ & 98.48 & 4.04 & 1161.00 \\
\hline SEm \pm & 1.0 & 0.09 & 0.09 \\
\hline $\mathrm{CD}(\mathrm{P}=0.05)$ & 3.90 & NS & NS \\
\hline \multicolumn{4}{|c|}{ Sub Plots: Nitrogen (N) Levels $\left(\mathrm{kg} \mathrm{ha}^{-1}\right)$} \\
\hline $\mathbf{N}_{1}: 120$ & 98.38 & 3.25 & 1224 \\
\hline $\mathbf{N}_{2}: 160$ & 105.48 & 4.56 & 1244 \\
\hline $\mathbf{N}_{3}: 200$ & 105.65 & 4.64 & 1268 \\
\hline SEm \pm & 0.98 & 0.04 & 1.41 \\
\hline $\mathrm{CD}(\mathrm{P}=0.05)$ & 3.04 & 0.14 & NS \\
\hline \multicolumn{4}{|l|}{ Interaction } \\
\hline \multicolumn{4}{|l|}{$\mathbf{N}$ at same level of $\mathbf{S}$} \\
\hline $\mathrm{SEm} \pm$ & 1.73 & 0.16 & 1.23 \\
\hline $\mathrm{CD}(\mathrm{P}=0.05)$ & NS & NS & NS \\
\hline \multicolumn{4}{|l|}{$\begin{array}{l}\text { S at same or different level } \\
\text { of } \mathbf{N}\end{array}$} \\
\hline SEm \pm & 1.71 & 0.11 & 0.19 \\
\hline $\mathrm{CD}(\mathrm{P}=0.05)$ & NS & NS & NS \\
\hline
\end{tabular}


Table.2 Significant interaction between irrigation regimes and nitrogen levels for grain yield

\begin{tabular}{|c|c|c|c|}
\hline Treatment & $\begin{array}{l}\text { Panicles/ } \\
\text { m2 }\end{array}$ & $\begin{array}{l}\text { grains/ } \\
\text { panicle }\end{array}$ & $\begin{array}{l}1000 \text { grain } \\
\text { weight }\end{array}$ \\
\hline \multicolumn{4}{|l|}{ Main Plots: Irrigation Regimes (S) } \\
\hline $\begin{array}{l}\mathrm{S}_{1} \text { - Transplanted low land rice with } \\
\text { continuous submergence of } 3 \mathrm{~cm} \text { up to } \\
\text { panicle initiation stage and then } 5 \mathrm{~cm} \text { up to } \\
\text { maturity }\end{array}$ & 300.55 & 158.63 & 24.76 \\
\hline $\begin{array}{l}\mathrm{S}_{2} \text {-AWD water management of periodical } \\
\text { flooding to } 3 \mathrm{~cm} \text { submergence depth from } \\
15 \text { DAT to maturity when the ponded } \\
\text { water disappears on the ground surface. }\end{array}$ & 299.11 & 158.43 & 25.43 \\
\hline $\begin{array}{l}\mathrm{S}_{3} \text { - AWD water management of periodical } \\
\text { flooding of the field to } 5 \mathrm{~cm} \text { submergence } \\
\text { depth from } 15 \text { DAT to maturity when the } \\
\text { ponded water level drops to } 5 \mathrm{~cm} \text { below } \\
\text { ground level in the field water tube. }\end{array}$ & 282.88 & 142.77 & 24.01 \\
\hline SEm \pm & 2.04 & 0.09 & 0.16 \\
\hline $\mathrm{CD}(\mathrm{P}=0.05)$ & NS & NS & NS \\
\hline \multicolumn{4}{|l|}{ Sub Plots: Nitrogen (N) Levels $\left(\mathrm{kg} \mathrm{ha}^{-1}\right)$} \\
\hline$N_{1}: 120$ & 291 & 143 & 24.22 \\
\hline $\mathrm{N}_{2}: 160$ & 293 & 158.0 & 24.59 \\
\hline$N_{3}: 200$ & 297 & 158.6 & 25.52 \\
\hline SEm \pm & 2.37 & 0.04 & 0.12 \\
\hline $\mathrm{CD}(\mathrm{P}=0.05)$ & NS & 0.14 & NS \\
\hline \multicolumn{4}{|l|}{ Interaction } \\
\hline \multicolumn{4}{|l|}{$\mathbf{N}$ at same level of $\mathbf{S}$} \\
\hline SEm \pm & 1.73 & 0.16 & 0.23 \\
\hline $\mathrm{CD}(\mathrm{P}=0.05)$ & NS & NS & NS \\
\hline \multicolumn{4}{|l|}{ S at same or different level of $\mathbf{N}$} \\
\hline SEm \pm & 1.71 & 0.11 & 0.28 \\
\hline $\mathrm{CD}(\mathrm{P}=0.05)$ & NS & NS & NS \\
\hline
\end{tabular}

This limits the ability of the roots to respire, thereby slowing down $\mathrm{N}$-uptake and transport and also slowing the rate of metabolism and growth (Lin et al., 2006 and Wang et al., 2011).

\section{Nitrogen levels}

The rice plants fertilized with $200 \mathrm{~kg} \mathrm{~N} / \mathrm{ha}$ were tallest with the maximum LAI and dry matter accumulation compared with the other lower $\mathrm{N}$ levels (Table 1). Nitrogen plays an important role in the cell growth and developments of rice plant (Dhar et al., 2000). Application of $200 \mathrm{~kg} \mathrm{~N} / \mathrm{ha}$ resulted in maximum panicles $/ \mathrm{m} 2$, grains/panicle than the $120 \mathrm{~kg} \mathrm{~N} / \mathrm{ha}$ (Table 2). Increased application of nitrogen from 90 to $180 \mathrm{~kg} / \mathrm{ha}$ under saturated condition upto PI stage followed by submergence might have led to availability of $\mathrm{N}$ in sufficient quantities required by the crop which encouraged the 
increased sink formation led to higher number of panicles, filled grains. These results are in line with Santhosh et al., (2013). There was a significant interaction between irrigation regimes and nitrogen levels for grain yield (Table 2). In all the three irrigation regimes, the grain yield was significantly increased by the additional input of $40 \mathrm{~kg} \mathrm{~N} / \mathrm{ha}$ starting from 120 upto $200 \mathrm{~kg} \mathrm{~N} / \mathrm{ha}$. Highest grain yield was noticed with the continuous submergence of $3 \mathrm{~cm}$ up to panicle initiation stage and then $5 \mathrm{~cm}$ up to maturity followed by saturation and $200 \mathrm{~kg} \mathrm{~N} / \mathrm{ha}$ which was superior to 120 and $160 \mathrm{~kg} \mathrm{~N} / \mathrm{ha}$ at all the irrigation.

\section{References}

Bouman, B.A.M., Hengsdjik, H., Hardy, B., Bindraban, P.S., Toung, T.P. and Ladha, J.K. (2002). Water wise rice production. Proceedings of the international workshop on water wise rice production, Los Banos Philippines. International Rice Research Institute. 938.

Dar, S. A., Bali, A.S and Shah, M. H. (2000). Effect of different levels and time of nitrogen application on wet-seeded rice in Kashmir Valley. Oryza. 37 (3): 244246.
Lin, X., Zhou, W., Zhu, D., Chen, H., Zhang, Y. (2006). Nitrogen accumulation, remobilization and portioning in rice under an improved irrigation condition. Field Crops Research. 96: 67-75

Santhoshkumar, G., SrinivasaRaju, $M$ and Mahender Kumar, R. (2013). Production potentialities of rice genotypes as influenced by nitrogen levels. Indian Journal of Agricultural Research, 47 (2): 169-172.

Tuong, T. P. and B. A. M. Bouman (2003). Rice production in water scarce environment; the comprehensive Assessment of water Management in Agriculture Series. 13-42.

Wang, X., Suo, Y., Feng, Y., Shohag, M. J.I and Lin, X (2011). Recovery of Nlabelled urea and soil nitrogen dynamics as affected by irrigation management and nitrogen application rate in a double rice cropping system. Plant soil. 343: 195-208.

Zhang, H., Chen, T.T., Wang, Z.Q., Yang, J.C. and Zhang, J.H. (2010). Involvement of cytokinin in the grain filling of rice under alternate wetting and drying irrigation. Journal of Experimental Botany. 61(13): 37193733.

\section{How to cite this article:}

Srinivasulu, P., V. Ramulu, M. Uma Devi and Sreenivas, G. 2018. Influence of Irrigation Regimes and Nitrogen Levels on Growth, Yield and Water Productivity of Rice under Alternate Wetting and Drying (AWD) Method of Water Management. Int.J.Curr.Microbiol.App.Sci. 7(04): 3307-3311. doi: https://doi.org/10.20546/ijcmas.2018.704.374 